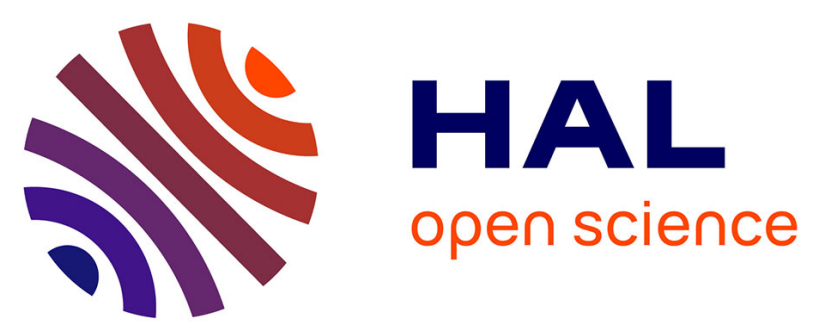

\title{
Human Chorionic Gonadotropin Expression in Human Trophoblasts from Early Placenta: Comparative Study Between Villous and Extravillous Trophoblastic Cells.
}

Karen Handschuh, Jean Guibourdenche, Vassilis Tsatsaris, Mickaël Guesnon, Ingrid Laurendeau, Danièle Evain-Brion, Thierry Fournier

\section{To cite this version:}

Karen Handschuh, Jean Guibourdenche, Vassilis Tsatsaris, Mickaël Guesnon, Ingrid Laurendeau, et al. Human Chorionic Gonadotropin Expression in Human Trophoblasts from Early Placenta: Comparative Study Between Villous and Extravillous Trophoblastic Cells.: hCG in invasive extravillous cytotrophoblast. Placenta, 2007, 28 (2-3), pp.175-184. 10.1016/j.placenta.2006.01.019 . inserm00000052

\section{HAL Id: inserm-00000052 https://www.hal.inserm.fr/inserm-00000052}

Submitted on 2 Jun 2006

HAL is a multi-disciplinary open access archive for the deposit and dissemination of scientific research documents, whether they are published or not. The documents may come from teaching and research institutions in France or abroad, or from public or private research centers.
L'archive ouverte pluridisciplinaire HAL, est destinée au dépôt et à la diffusion de documents scientifiques de niveau recherche, publiés ou non, émanant des établissements d'enseignement et de recherche français ou étrangers, des laboratoires publics ou privés. 


\section{Author Manuscript}

\section{Human Chorionic Gonadotropin expression in human trophoblasts from early placenta: comparative study between villous and extravillous trophoblastic cells.}

Karen Handschuh ${ }^{a}$, Jean Guibourdenche ${ }^{\text {a, b }}$, Vassilis Tsatsaris ${ }^{\text {a, c }}$, Mickaël Guesnon ${ }^{\text {a }}$, Ingrid Laurendeau ${ }^{d}$, Danièle Evain-Brion ${ }^{a}$ and Thierry Fournier ${ }^{\text {a }}$

${ }^{a}$ INSERM, U427, Faculté des Sciences Pharmaceutiques et Biologiques, Université René Descartes, Paris 5, 75006 Paris, France

${ }^{\mathrm{b}}$ Biochimie, Hôpital Debré APHP, 48 boulevard Sérurier, 75935 Paris 19, France

${ }^{\mathrm{c}}$ Maternité Port-Royal, Hôpital Cochin, Université René Descartes, Paris 5, France

${ }^{\mathrm{d}}$ Laboratoire de génétique moléculaire, UPRES EA 3618, Faculté des Sciences Pharmaceutiques et Biologiques, Université René Descartes, Paris 5, 75006 Paris, France

Corresponding author to whom all correspondence should be addressed: Thierry Fournier, INSERM, U427, Faculté de Pharmacie, 75006 Paris, France

TEL: 33(1) 537396 03; FAX 33(1) 440739 92; E-MAIL Thierry.Fournier@univ-paris5.fr

Short title: hCG in invasive extravillous cytotrophoblast

Key words: cytotrophoblast, syncytiotrophoblast, placental hormone, differentiation, invasion 


\begin{abstract}
Human trophoblast differentiates into two pathways: extravillous cytotrophoblasts (EVCT) that invade the uterus wall and villous cytotrophoblasts (VCT) that fuse to form the syncytiotrophoblast (ST) involved in placental exchanges and endocrine function. It is established that hCG is produced and secreted by the ST into the maternal compartment where it plays a key endocrine role and stimulates ST formation in an autocrine manner. Herein, we investigated hCG expression in early placentas by immunohistochemistry using different antibodies. We then compared hCG secretion by primary cultures of VCT and EVCT isolated from the same first trimester human chorionic villi. In situ hCG was immunodetected in EVCT all along their invasive differentiating pathway excepted in cells near the stromal core of the proximal column. hCG expression was confirmed in vitro by immunocytochemistry and hCG secretion quantified in cell supernatants. Interestingly, whereas hCG secretion increased during VCT differentiation into ST (from 60 to $350 \mathrm{UI} / \mathrm{L} / \mu \mathrm{g}$ DNA), EVCT secretion remained constant and at a high level during the same culture period (160 UI/L/ $\mu \mathrm{g}$ DNA). Our data demonstrated that in addition to the ST, invasive EVCT also expressed and secreted high levels of hCG, suggesting a specific paracrine and/or autocrine role for hCG from EVCT origin.
\end{abstract}




\section{Introduction}

After implantation, human trophoblasts follow two differentiation pathways: the villous and the extravillous cytotrophoblasts that display different phenotypes and functions (cf. Fig. 2A). The mononucleated villous cytotrophoblasts (VCT) that cover the floating chorionic villi aggregate and fuse to form a multinucleated syncytiotrophoblast (ST), which is involved in the exchange of gases and nutrients between the mother and the fetus. Moreover, the ST represents the endocrine tissue of the placenta, secreting large amounts, unparalleled in other mammals, of protein hormones including human chorionic gonadotropin hormone (hCG) (1). The trophoblasts located at the tip of the anchoring villi contacting the uterine wall follow a different differentiation pathway. These trophoblasts, named extravillous cytotrophoblasts (EVCT), proliferate to form multilayered columns of cells and then invade the decidua up to the upper third of the myometrium. At the deciduo-muscular junction, EVCT undergo a final differentiation into multinucleated giant cells. Trophoblastic infiltration of the arterial wall is accompanied by dramatic structural changes of the vascular media such as the lost of elastic fibres and smooth muscle cells which are usely attributed to proteolytic activities of the invasive endovascular cells (2). Hence, EVCT are directly involved in the anchoring of chorionic villi in the uterus, and in the essential remodeling of the uterine arterioles to provide adequate supply of maternal blood to the intervillous space necessary for fetal growth (3-7).

Human chorionic gonadotropin hormone, specific to humans and great apes, is a glycoprotein composed of an alpha subunit ( $\alpha$ hCG), which is common to other peptide hormones such as LH (luteinizing hormone), FSH (follicle stimulating hormone) and TSH (thyroid stimulating hormone), and a beta subunit ( $\beta$ hCG), which confers the biological specificity of the hormone $(8,9)$. $\alpha$ hCG is encoded by a single gene and $\beta$ hCG by 6 genes of which the CGß5 gene is expressed predominantly in the placenta $(10,11)$. After implantation, hCG is the first trophoblast signal detected in the maternal blood and is used as a diagnostic marker of pregnancy. hCG and its free $\beta$ subunit are detected in the maternal blood from the 
second week of pregnancy with peak levels at twelve weeks and then gradually decrease; $\alpha$ hCG levels increase progressively up to term (12). Maintenance of pregnancy during the first trimester depends on the synthesis of hCG, which prevents regression of the corpus luteum (13) allowing the maintenance of ovarian progesterone secretion (1). In addition to its well-established endocrine role, hCG plays an autocrine/paracrine role in human trophoblast differentiation (14, $15)$.

Although the synthesis and secretion of hCG by the villous trophoblast is well established and documented (16), presence of hCG in the cytotrophoblast from extravillous origin remains controversial since opposite results were reported by different authors (17-19). Therefore, in the present study we first investigated in situ the localization of hCG at the feto-maternal interface using different antibodies. Then, we examined the in vitro expression and secretion of hCG in cultured villous and extravillous cytotrophoblasts isolated from the same chorionic villi of first trimester human placentas, and compared quantitatively the hCG secretion of each cytotrophoblastic cell type. 


\section{Materials and Methods}

\section{Materials}

Placental tissues from patients who voluntarily and legally chose to terminate pregnancy during the first trimester (8-12 wk of gestation) were obtained from Broussais Hospital (Paris, France, $\mathrm{n}=14)$. All patients gave informed consent. We also obtained paraffin sections of an implantation site (placenta and myometrium) at $16 \mathrm{wk}$ of gestation from the pathology department of "La Citadelle Hospital" (Liège, Belgium). Hysterectomy was performed because of cervical carcinoma stage IIa diagnosed at $15 \mathrm{wk}$.

\section{Immunohistochemistry}

Samples from 8-12 wk placentas were either fixed by incubation in $4 \%$ formalin for 4 to $24 \mathrm{~h}$ at room temperature and then embedded in paraffin $(\mathrm{n}=3)$, or embedded in TissueTek, frozen in isopentan and kept at $-80^{\circ} \mathrm{C}$ until use $(n=4)$. Paraffin sections of the $8-12$ wk placentas and of the 16 wk of gestation implantation site (placenta and myometrium obtained from Belgium) were dewaxed in xylene and rehydrated in ethanol/water. Sections were then incubated for 45 min in citrate buffer at $90^{\circ} \mathrm{C}$ for antigen retrieving. Immunostaining was performed with a streptavidin-peroxidase immunostaining kit (Peroxidase, Dako, LSAB ${ }^{\circledR}+$ Kit DAKOC , Trappes, France). Samples were permeabilized for $4 \mathrm{~min}$ in $0.3 \%$ Triton X-100 (for cytokeratin 7 (CK7) and Ki67 immunodetections only) and non-specific binding was blocked by incubation for 5 min in a blocking reagent containing $3 \% \mathrm{H}_{2} \mathrm{O}_{2}$ and then in $3 \%$ serum albumin in PBS buffer for 30 min. The sections were incubated with several antibodies directed against different hCG epitops, with an anti-Ki67 antibody and with an anti-CK07 antibody for $30 \mathrm{~min}$ at room temperature.

Characteristics for each antibody are detailed in Table 1. Sections were washed in PBS and incubated with a biotinylated secondary antibody for $15 \mathrm{~min}$. They were then washed 3 times in PBS and incubated with streptavidin conjugated to horse-radish peroxidase for $15 \mathrm{~min}$. The sections were washed in PBS and staining was detected by incubation for 2 min with the DAB (3,3'-diaminobenzidine) chromogen. Controls were performed by incubating the sections with 
nonspecific IgG at the same concentration as the primary antibody. Preparations were counterstained with hematoxylin blue (except for Ki67 staining) and mounted in an aqueous mounting medium (Aqueous Mounting Medium, DAKO®), Trappes, France), then examined and photographed with an Olympus BX60 microscope.

\section{Isolation and Purification of villous (VCT) and extravillous (EVCT) cytotrophoblasts}

Seven different isolations of EVCT and VCT were performed using seven independent human chorionic villi from first trimester legally induced abortion. EVCT and VCT were each time isolated from the same chorionic villi by differential trypsin digestion according to the methods of Tarrade et al (20) with slight modifications. Chorionic villi were washed, dissected and rinsed in $\mathrm{Ca}^{2+}, \mathrm{Mg}^{2+}$-free HBSS supplemented with $100 \mathrm{UI} / \mathrm{mL}$ penicillin and $100 \mu \mathrm{g} / \mathrm{mL}$ streptomycin.

For EVCT isolation, the tissue was incubated in HBSS $(5 \mathrm{~mL} / \mathrm{g})$ containing $0.125 \%$ trypsin (Difco Laboratories, Detroit, Michigan), $4.2 \mathrm{mM} \mathrm{MgSO}_{4}, 25 \mathrm{mM}$ Hepes, $50 \mathrm{U} / \mathrm{mL}$ Dnase type IV (Sigma, Saint-Quentin Fallavier, France) for $35 \mathrm{~min}$ at $37^{\circ} \mathrm{C}$ without agitation. After tissue sedimentation, the supernatant containing isolated EVCT was filtered (100 $\mu \mathrm{m})$ and stored in the presence of $10 \%(\mathrm{v} / \mathrm{v})$ fetal calf serum (FCS) to inhibit trypsin activity. The tissue was washed five to six times with warm HBSS and supernatant fractions were pooled. Cells were centrifuged at $300 \mathrm{Xg}$ for $10 \mathrm{~min}$, washed twice in HBSS supplemented with $10 \%$ FCS and filtered on a $50 \mu \mathrm{m}$ pore nylon membrane. The cell suspension was carefully layered over a discontinuous Percoll gradient and centrifuged for $25 \mathrm{~min}$ at $1000 \mathrm{X}$ g. The layer corresponding to $40-45 \%$ Percoll containing cytotrophoblasts was washed twice in HBSS supplemented with $10 \%$ FCS. Cells were diluted to a concentration of $2.5 \times 10^{5}$ cells/mL in HAM-F12/DMEM (v/v) supplemented with $10 \%$ FCS, $2 \mathrm{mM}$ glutamine, $100 \mathrm{UI} / \mathrm{mL}$ penicillin and $100 \mu \mathrm{g} / \mathrm{mL}$ streptomycin and plated at a density of 50000 cells per $\mathrm{cm}^{2}$ on Matrigel-coated $(5 \mathrm{mg} / \mathrm{mL}$; BD Biosciences, Le Pont-de-Claix, France) 35-mm Falcon culture dishes. After $2 \mathrm{~h}$ of culture in 5\% $\mathrm{CO}_{2}$ at $37^{\circ} \mathrm{C}$, cells were carefully washed three times to eliminate nonadherent cells. Each 
preparation of purified EVCT was characterized using immunocytochemistry and real-time PCR and $97 \%$ of cells were shown to express in vitro the specific markers of human invasive EVCT in situ as described previously i.e., cytokeratin 7, human leukocyte antigen G (HLA-G), CD9, human placental lactogen, $c$-erbB2 and $\alpha 5 \beta 1$ and were negative to vimentin $(20,21)$ and as recently published (22). These purified EVCT were non proliferative and highly invasive on Matrigel-coated transwells or dishes (23).

VCT isolation is based on the protocol of Kliman et al (16) and is a modified version of the Tarrade et al protocol (20). After EVCT isolation, the same chorionic villi were incubated for $30 \mathrm{~min}$ at $37^{\circ} \mathrm{C}$ without agitation in $5 \mathrm{~mL} / \mathrm{g}$ of tissue of the digestion buffer described above but containing only $0.0625 \%$ trypsin. The first 30 min trypsin digestion, containing a mix of EVCT and VCT, was discarded. The chorionic villi were then incubated in the same trypsin solution for $30 \mathrm{~min}$ and twice for $15 \mathrm{~min}$ at $37^{\circ} \mathrm{C}$ without agitation, and finally washed with warm HBSS. Each time, the supernatant containing VCT was collected after tissue sedimentation, filtered (100 $\mu \mathrm{m})$, and incubated on ice with $10 \%$ FCS (v/v) to stop trypsin activity. After Percoll gradient fractionation, cells were diluted to a concentration of $1.25 \times 10^{6} \mathrm{ce} / 1 \mathrm{~s} / \mathrm{mL}$ in DMEM supplemented with $10 \%$ FCS, $2 \mathrm{mM}$ glutamine, $100 \mathrm{UI} / \mathrm{mL}$ penicillin and $100 \mu \mathrm{g} / \mathrm{mL}$ streptomycin and plated at a density of 150000 cells per $\mathrm{cm}^{2}$ on $35-\mathrm{mm}$ or $60-\mathrm{mm}$ TPP (Techno Plastic Products) tissue culture dishes. VCT were incubated overnight in $5 \% \mathrm{CO}_{2}$ at $37^{\circ} \mathrm{C}$ and washed three times to eliminate non-adherent cells. Purified VCT cultures were characterized by positive staining for CK7 (95\% positive cells) and by the observation of cell aggregates and syntytiotrophoblasts from 48 to $72 \mathrm{~h}$.

\section{hCG Immunocytochemistry}

\section{hCG simple labelling}

EVCT and VCT were fixed for $20 \mathrm{~min}$ in $4 \%$ paraformaldehyde after 24 to $72 \mathrm{~h}$ of primary culture. Cells were rinsed three times with PBS and immunostained for hCG (HT13 antibody, see Table 1) using a streptavidin-peroxidase immunostaining kit (Peroxidase, Dako, 
LSAB® ${ }^{\circledR}$ Kit, DAKO $@$, Trappes, France) as described for immunohistochemistry.

\section{hCG / Ki67 double labelling}

EVCT were fixed for $20 \mathrm{~min}$ in $4 \%$ paraformaldehyde after 2 and $48 \mathrm{~h}$ of primary culture on Matrigel. Cells were rinsed three times with PBS and permeabilized 4 min in Triton $0.3 \%$. Saturation of unspecific sites was performed in $7 \%$ donkey and goat serum diluted in PBS for $1 \mathrm{~h}$ at room temperature. Primary antibodies (monoclonal mouse anti-Ki67, 1/100 and polyclonal rabbit anti-hCG A0231, 1/1000, DAKO, France) diluted in PBS containing 1\% BSA were added for $2 \mathrm{~h}$ at room temperature and amplified with the secondary antibody (CY3-conjugated donkey anti-mouse IgG1 and FITC-conjugated goat anti-rabbit IgG, 1/300, Jackson Immunoresearch Laboratories, West Groove, PA) diluted in PBS for $1 \mathrm{~h}$ in dark at room temperature. Cells were mounted in a fluorescent Dapi mounting medium, examined and photographed on an Olympus BX60 epifluorescence microscope.

Controls were performed by incubating the cells with a non specific IgG at the same concentration as the primary antibody.

\section{Immunoblotting}

Four couples of ST and EVCT isolated from the same chorionic villi were analysed. Each culture medium was separated by $4-12 \%$ sodium dodecyl sulfate-polyacrylamide gel electrophoresis in $\mathrm{pH} 7$ running buffer. After transfer, detection was enhanced by the Quentix ${ }^{\mathrm{TM}}$ Western Blot Signal Enhancer Kit (Pierce, Rockford IL, USA). On blots, hCG was detected with A0231 antibody (1/500) itself detected using horseradish peroxidase-conjugated sheep anti-rabbit IgG antibodies (1/40000) and enhanced chemiluminescence reagents (Pierce, Rockford IL, USA).

\section{Hormone assays}

Total hCG was determined using the chemiluminescent immunoassay analyzer ACS- 
180SE system (Bayer Diagnostics, Westwood CA, USA). The assay used for total hCG quantification was a sandwich immunoassay that recognized free $\beta$-subunit, nicked and intact hCG. Two antibodies were used: a capture mouse monoclonal anti-hCG antibody and a labelled polyclonal goat anti-hCG antibody, which were raised against two different epitopes of the $\beta$ subunit of hCG. Performance characteristics were as follows: range 2-1000 UI/L; within-run precision $2.8 \%$ and between-run precision 5.6\%; functional detection limit 1 UI/L. Samples were diluted $(1 / 100)$ in the reaction buffer when necessary. In order to compare the secretion of hCG in VCT and EVCT supernatants, results were normalized to one $\mu \mathrm{g}$ of DNA.

\section{DNA quantification}

Cell pellets were solubilized in $5 \mathrm{M}$ GuSCN, $0.1 \mathrm{M}$ EDTA, $\mathrm{pH} 7$ and stored at $-80^{\circ} \mathrm{C}$ until use. DNA was quantified by fluorometry using the fluorochrome Hœchst 33258 as described by Labarca and Paigen (24).

\section{Statistical analysis}

Values represent the mean \pm SEM of 3 separate cultures obtained from different placentas. The Mann and Whitney (*) test was used to compare EVCT vs VCT. The Kruskal and Wallis test (\$) was used to compare protein secretion from 24-, 48- and 72-h VCT cultures. Results were considered significant when $P<0.05$. 


\section{RESULTS}

\section{In situ immunodetection of hCG at the implantation site}

To date, the presence of hCG in EVCT along their differentiating and invasive pathway remains controversial. Therefore, we first examined the expression of hCG in human placentas from 8 to $16 \mathrm{wk}$ of gestation by immunohistochemistry. Placental portions were either embedded in TissueTek and frozen or fixed with formalin for $4 \mathrm{~h}$ or for 12 to $24 \mathrm{~h}$. Three anti-hCG antibodies were used in the present study (Table 1): the HT13 monoclonal antibody raised against the $\alpha$-subunit of hCG; the FB12 monoclonal and the A0231 polyclonal antibodies both raised against the $\beta$-subunit of hCG. These three antibodies recognized both the free subunit $(\alpha$ or $\beta)$ and total hCG.

Results are summarized in Table 2. Irrespective of the fixation and antibodies used, the profound myometrium remained negative for hCG immunostaining. VCT and ST known to express hCG were labelled in all conditions except with the FB12 antibody after a 4-h formalin fixation. In EVCT a positive labelling was found using the polyclonal A0231 antibodies in all conditions. Using the FB12 antibody, hCG was immunodetected in EVCT only on frozen section whereas the HT13 antibody detected hCG in EVCT on paraffined sections after a short formalin fixation time $(4 \mathrm{~h})$.

Figure 1 depicts a representative immunohistochemistry experiment obtained after fixation of the 16 wk-placenta sections for $4 \mathrm{~h}$ in formalin and immunostained for hCG (Fig. 1A: A0231 antibody, Fig. 1B: HT13 antibody), for Ki67 (Fig. 1C) and with isotypic IgG used as control (Fig. 1D). Zoom of different sites from sections immunostained with the HT13 antibody are presented in Fig 2. As shown in Figure 1 and 2, syncytiotrophoblast, villous and extravillous cytotrophoblasts were stained positively with HT13 and A0231 antibodies. As shown in Fig. 1 A\&B and in Fig. 2 C, E, \& F all types of EVCT along their differentiating pathway stained positive for hCG, i.e. EVCT from the column (zoom in Fig. 2E), invasive EVCT (zoom in Fig. 2F), endovascular EVCT (zoom in Fig. 2F) and giant multinucleated cells (zoom in Fig. 2C). A 
few cytokeratin 7 negative cells in the stromal core stained positive for hCG (Fig. 1A\&B), whereas profound myometrium remained negative (Fig. 2D).

We noticed that in the proximal column from first and second trimester placenta sections, most of the EVCT located at the tip of the villi close to the stromal core were not immunostained for hCG and were positive for Ki67 (Fig. 1A-C and Fig.3 A\&B). EVCT distant from the stromal core became positive for hCG (Fig. 1A, B, Fig.2E and Fig.3 A) and most of the EVCT from the distal column were immunostained (Fig. 1A, B and Fig. 2E). Most of these cells were still positive for Ki67 (Fig. 1C and Fig.3B). Finally, invasive EVCT in the decidua and endovascular EVCT were all positive for hCG (Fig. 1A\&B, Fig 2E\&F) and negative for Ki67 (Fig. 1C).

We next examined the phenotype of extravillous cells isolated from first trimester chorionic villi and cultured on Matrigel (Fig. 3C-F). We observed that at $2 \mathrm{~h}$ of culture (Fig 3C\&D) $65 \%$ of EVCT were positive for Ki67, 30\% were positive for hCG and $15 \%$ were hCG / Ki67 double positive. At 48 h (Fig. 3E\&F), most of the invasive EVCT (93\%) were exclusively hCG positive and only 7\% of EVCT were double positive.

\section{Comparative expression of hCG in human VCT and EVCT primary cultures}

We investigated the in vitro expression of hCG in cultures of villous and extravillous cytotrophoblasts isolated from first trimester chorionic villi. Figures 4A\&B show immunodetection of hCG in cultured-VCT and EVCT. Mononucleated VCT in culture adhered to plastic dishes, aggregated at $48 \mathrm{~h}$ and fused to form a multinucleated syncytiotrophoblast at $72 \mathrm{~h}$ (Fig. 4A). EVCT require extracellular matrix-coated dishes for adhesion and culture, they display an invasive phenotype and emitt pseudopodia (20). Using HT13 (Fig. 4A\&B) and A0231 (data not shown) antibodies, hCG was immunodetected in VCT at all stages of their differentiating pathway into ST (Fig. 4A) and in invasive EVCT at each time point (Fig. 4B). No staining was obtained neither in VCT nor in EVCT using isotypic IgG1 (Fig. 4A\&B, left panels).

We next analysed hCG secretion in culture media by immunoblotting. As shown in Fig. 4C, we detected hCG and its free $\beta$-subunit with A0231 antibody with a molecular apparent 
weight of $38 \mathrm{kD}$ and of $25 \mathrm{kD}$, respectively.

We finally quantified and compared the secretion of total hCG in VCT and EVCT culture supernatants after normalization to DNA content. As shown in Figure 4D and now well established, VCT secreted increasing amount of total hCG along their differentiation into ST. In contrast, EVCT showed a stable production of total hCG along the $72 \mathrm{~h}$ culture period. At $24 \mathrm{~h}$, EVCT secreted two-fold more total hCG than mononucleated VCT $(P<0.001)$. At $48 \mathrm{~h}$, total hCG secretion was identical in EVCT and aggregated VCT. As expected, the multinucleated ST at $72 \mathrm{~h}$ was the most potent hCG producer of total hCG $(P<0.01)$. 


\section{DISCUSSION}

In this study, we established that cytotrophoblasts from extravillous origin expressed the human chorionic gonadotropin hormone in situ all along their invasive pathway. These data were confirmed in vitro using invasive EVCT primary cultures obtained from first trimester human placentas. Indeed, in contrast with the well-established in vivo (25) and in vitro hCG expression in villous trophoblast $(16,26,27)$, the presence of hCG in EVCT has been investigated only by immunohistochemistry and results remained controversial. Although Gosseye and Fox have never detected this hormone in EVCT irrespective of the term studied (19), other authors have shown positive staining in different sub-types of EVCT. Results from Sasagawa et al, showed that the $\alpha$ - and $\beta$-subunits of hCG were restricted to the mononuclear trophoblast in the superficial decidua of first and second trimester placentas (17), whereas results from Kurman et al, showed that hCG was exclusively expressed by giant multinucleated cells in term placentas (18).

In the present study, using several antibodies (monoclonal and polyclonal) raised against different hCG epitopes, we showed that almost all sub-types of EVCT from 8 to 16 wk placental sections expressed hCG: cells from the column, invasive, endovascular and giant multinucleated cells. However, we noticed that a few EVCT from the proximal column in contact with the stromal core were negative for hCG staining. Most of the EVCT in the column were positive for Ki67, whereas invasive EVCT in the decidua were all negative. This suggests that during their differentiating pathway from proliferating cells in the column to invasive cells in the decidua, EVCT exit cell cycle and express hCG. Since induction and inhibition of gene expression are dynamic processes, EVCT co-expressing hCG and Ki67 were observed in situ as well as in vitro.

Our results suggest that hCG could be a marker of invasive extravillous cytotrophoblasts and might potentially play a role in trophoblast invasion as it has been proposed recently by assay on immortalized EVCT (28). The reason why we obtained different results than others is probably linked to the technical process. Because immunostaining is dependent of multiple factors such as the fixation step that determines the antigen structure and therefore the antibody 
specificity, in the present study we used both frozen and paraffin-fixed sections using various fixation times and three different antibodies. We showed in Table 2 that results differed dramatically depending on the antibody and tissue process. However, for each antibody we found the best compromise allowing the detection of hCG in both EVCT and VCT/ST from the same placental section, VCT and ST being considered as a positive control for the presence of hCG. We also found hCG positive cells in the mesenchymal stroma of chorionic villi, which probably correspond to macrophages called Hofbauer cells. Localization of hCG in human Hofbauer cells has been reported by others. They provided evidence that these macrophages ingest hCG secreted by the ST and play a role in degradation and production of nicked hCG (29).

We next studied the expression of hCG in vitro in a population of purified EVCT and VCT considered to be the main source of hCG. In the present study, human extravillous and villous cytotrophoblasts were isolated and purified from the same first trimester chorionic villi. They were characterized by immunocytochemistry using different antibodies according to the established differentiation markers specific for these two trophoblast lineages $(20,21,30,31)$. As previously described (20), these two trophoblast types have different behavior in culture. VCT adhere to plastic dishes, aggregate and fuse to form a syncytiotrophoblast. EVCT need an extracellular matrix for adhesion and culture, digest and invade this matrix. We previously showed that primary EVCT cultured on Matrigel are non proliferative cells (23) that acquire and display an invasive phenotype in vitro after a few hours of culture, as described by expression of specific markers and the ability to invade extracellular matrix in Boyden chambers $(20,32)$. Using these in vitro models, we confirmed by immunocytochemistry the presence of hCG in invasive EVCT. Using different methods of detection (hormonal assays and immunoblotting), we showed that, unexpectedly, EVCT produced high levels of hCG compared to cytotrophoblast of villous origin (intermediate between mononucleated VCT and ST). Furthermore, we found that the capacity of primary invasive EVCT to secrete hCG remained constant from 24 to $72 \mathrm{~h}$ of culture, whereas the secretory capacity of villous trophoblast increased during their differentiation into a ST as previously reported in cultures from early and term placentas $(16,27)$. 
This discrepancy is probably due to the fact that EVCT displayed the same invasive phenotype during the three-day study in contrast with VCT, which differentiate into ST.

An important role of hCG at the feto-maternal interface has been reported by different investigators $(33,34)$. LH/CG receptors have been described in EVCT (35) and in vascular endothelial cells (36). Our study strongly suggests that hCG secreted by invasive EVCT might act as autocrine and/or paracrine factor for EVCT differentiation and/or endothelial cells from the uterine arteries. Indeed, the regulatory effect of hCG in the invasion of the choriocarcinoma JEG3 (36) or of immortalized EVCT (28) have been reported and recent studies proposed hCG as a novel angiogenic factor (38). Further studies should increase the level of understanding as to the role of hCG produced by extravillous cytotrophoblast and its implication in trophoblast invasion and vascular remodeling.

In conclusion, this study used severals methods and antibodies to demonstrate that invasive extravillous cytotrophoblasts are a significant source of hCG that might play a role at the feto-maternal interface.

\section{Acknowledgments}

We thank the Department of Obstetrics and Gynecology at the Broussais Hospitals, Paris, France for providing placental tissues. We are also grateful to B. Genevois (Immunotech), I. Bazot (Bayer Diagnostics) and J.M. Bidart for providing the monoclonal hCG antibodies. This work was supported by "la Caisse d'Assurance Maladie des Professions Libérales-Province", CAMPLP, Paris la Défense, 92042, France. 


\section{References}

[1] Jameson JL \& Hollenberg AN Regulation of chorionic gonadotropin gene expression. Endocrine Reviews 1993; 14 :203-221.

[2] Benirschke K \& Kaufmann P Pathology of the human placenta, Fourth edition. 2000.

[3] Loke YW \& King A Human implantation. Cell Biology and Immunology, Cambridge ed. 1995

[4] Malassine A, Frendo JL \& Evain-Brion D A comparison of placental development and endocrine functions between the human and mouse model. Hum Reprod Update 2003; 9:531-9.

[5] Red-Horse K, Zhou Y, Genbacev O, Prakobphol A, Foulk R, McMaster M \& Fisher SJ Trophoblast differentiation during embryo implantation and formation of the maternal-fetal interface. J Clin Invest. 2004; 114:744-54.

[6] Georgiades P, Ferguson-Smith AC, Burton GJ. Comparative developmental anatomy of the murine and human definitive placentae. Placenta. $2002 ; 23: 3-19$. Review

[7] Kaufmann P, Black S, Huppertz B. Endovascular trophoblast invasion: implications for the pathogenesis of intrauterine growth retardation and preeclampsia. Biol Reprod. 2003; 69:1-7. Review.

[8] Pierce JG \& Parsons TF Glycoprotein hormones: structure and function. Annu Rev Biochem. 1981; 50:465-95.

[9] Hartree AS \& Renwick AGC Molecular structures of glycoprotein hormones and functions of their carbohydrate components. Biochem J. 1992; 287 :665-679.

[10] Jameson JL, Lindell CM, Hsu DW, Habener JF \& Ridgway EC Expression of chorionic gonadotropin-beta-like messenger ribonucleic acid in an alpha-subunit-secreting pituitary adenoma. J Clin Endocrinol Metab. 1986; 62:1271-8

[11] Bo M \& Boime I Identification of the transcriptionally active genes of the chorionic gonadotropin beta gene cluster in vivo. J Biol Chem. 1992; 267:3179-84.

[12] Jaffe RB, Lee PA \& Midgley AR Jr Serum gonadotropins before, at the inception of, and following human pregnancy. J Clin Endocrinol Metab. 1969; 29:1281-3. 
[13] Hay DL \& Lopata A Chorionic gonadotropin secretion by human embryos in vitro. J Clin Endocrinol Metab. 1988; 67:1322-4.

[14] Cronier L, Bastide B, Herve JC, Deleze J, Malassine A. Gap junctional communication during human trophoblast differentiation: influence of human chorionic gonadotropin. Endocrinology. 1994;135:402-8.

[15] Shi QJ, Lei ZM, Rao CV, Lin J. Novel role of human chorionic gonadotropin in differentiation of human cytotrophoblasts. Endocrinology. 1993;132:1387-95.

[16] Kliman HJ, Nestler JE, Sermasi E, Sanger JM \& Strauss JF 3rd Purification, characterization, and in vitro differentiation of cytotrophoblasts from human term placentae. Endocrinology . 1986; 118:1567-82.

[17] Sasagawa M, Yamazaki T, Endo M, Kanazawa K \& Takeuchi S Immunohistochemical localization of HLA antigens and placental proteins (alpha hCG, beta hCG CTP, hPL and SP1 in villous and extravillous trophoblast in normal human pregnancy: a distinctive pathway of differentiation of extravillous trophoblast. Placenta 1987; 8:515-28

[18] Kurman RJ, Young RH, Norris HJ, Main CS, Lawrence WD \& Scully RE Immunocytochemical localization of placental lactogen and chorionic gonadotropin in the normal placenta and trophoblastic tumors, with emphasis on intermediate trophoblast and the placentaire site trophoblastic tumor. Int J Gynecol Pathol 1984; 3:101-21.

[19] Gosseye S \& Fox H An immunohistological comparison of the secretory capacity of villous and extravillous trophoblast in the human placenta. Placenta. 1984; 5:329-47.

[20] Tarrade A, Lai Kuen R, Malassine A, Tricottet V, Blain P, Vidaud M \& Evain-Brion D Characterization of human villous and extravillous trophoblasts isolated from first trimester placenta. Lab Invest. 2001; 81:1199-211.

[21] Pavan L, Tarrade A, Hermouet A, Delouis C, Titeux M, Vidaud M, Therond P, EvainBrion D \& Fournier T Human invasive trophoblasts transformed with simian virus 40 provide a new tool to study the role of PPARgamma in cell invasion process. Carcinogenesis. 2003; $24: 1325-36$. 
[22] Malassine A, Handschuh K, Tsatsaris V, Gerbaud P, Cheynet V, Oriol G, Mallet F, Evain-Brion D. Expression of HERV-W Env glycoprotein (syncytin) in the extravillous trophoblast of first trimester human placenta. Placenta. 2005; 26:556-62.

[23] Tarrade A, Goffin F, Munaut C, Lai-Kuen R, Tricottet V, Foidart JM, Vidaud M, Frankenne F \& Evain-Brion D Effect of matrigel on human extravillous trophoblasts differentiation: modulation of protease pattern gene expression. Biol Reprod. 2002; 67:1628-37.

[24] Labarca C \& Paigen K A simple, rapid, and sensitive DNA assay procedure. Anal Biochem 1980; 102:344-52.

[25] Hoshina M, Boothby M \& Boime I Cytological localization of chorionic gonadotropin alpha and placental lactogen mRNAs during development of the human placenta. J Cell Biol. 1982; 93:190-8.

[26] Knofler M, Saleh L, Strohmer H, Husslein P \& Wolschek MF Cyclic AMP- and differentiation-dependent regulation of the proximal alpha HCG gene promoter in term villous trophoblasts. Mol Hum Reprod 1999; 5:573-80.

[27] Frendo JL, Vidaud M, Guibourdenche J, Luton D, Muller F, Bellet D, Giovagrandi Y, Tarrade A, Porquet D, Blot P \& Evain-Brion D Defect of villous cytotrophoblast differentiation into syncytiotrophoblast in Down's syndrome. J Clin Endocrinol Metab. 2000; $85: 3700-7$

[28] Zygmunt M, McKinnon T, Herr F, Lala PK, Han VK. HCG increases trophoblast migration in vitro via the insulin-like growth factor-II/mannose-6 phosphate receptor. Mol Hum Reprod. 2005; 11:261-7.

[29] Katabuchi H, Fukumatsu Y, Araki M, Mizutani H, Ohba T \& Okamura H Localization of chorionic gonadotropin in macrophages of the human chorionic villi. Endocr J. 1994; 41 :S141-S153.

[30] King A, Thomas $\mathbf{L} \&$ Bischof $\mathbf{P}$ Cell culture models of trophoblast II: trophoblast cell lines--a workshop report. Placenta 2000; 21 Suppl A:S113-9.

[31] Shiverick KT, King A, Frank H, Whitley GS, Cartwright JE \& Schneider H Cell 
culture models of human trophoblast II: trophoblast cell lines--a workshop report. Placenta. 2001; 22 Suppl A:S104-6.

[32] Tarrade A, Schoonjans K, Pavan L, Auwerx J, Rochette-Egly C, Evain-Brion D \& Fournier T PPARgamma/RXRalpha heterodimers control human trophoblast invasion. J Clin Endocrinol Metab. 2001; 86:5017-24.

[33] Han SW, Lei ZM \& Rao CV Treatment of human endometrial stromal cells with chorionic gonadotropin promotes their morphological and functional differentiation into decidua. Mol Cell Endocrinol. 1999;147:7-16.

[34] Zhou XL, Lei ZM \& Rao CV Treatment of human endometrial gland epithelial cells with chorionic gonadotropin/luteinizing hormone increases the expression of the cyclooxygenase- 2 gene. J Clin Endocrinol Metab. 1999; 84:3364-77.

[35] Tao YX, Lei ZM, Hofmann GE \& Rao CV Human intermediate trophoblasts express chorionic gonadotropin/luteinizing hormone receptor gene. Biol Reprod 1995; 53:899-904

[36] Toth P, Li X, Rao CV, Lincoln SR, Sanfilippo JS, Spinnato JA 2nd \& Yussman MA Expression of functional human chorionic gonadotropin/human luteinizing hormone receptor gene in human uterine arteries. J Clin Endocrinol Metab. 1994; 79:307-15

[37] Zygmunt M, Hahn D, Munstedt K, Bischof P \& Lang U Invasion of cytotrophoblastic JEG-3 cells is stimulated by hCG in vitro. Placenta. 1998; 19(8):587-93.

[38] Zygmunt M, Herr F, Keller-Schoenwetter S, Kunzi-Rapp K, Munstedt K, Rao CV, Lang U \& Preissner KT Characterization of human chorionic gonadotropin as a novel angiogenic factor. J Clin Endocrinol Metab. 2002; 87:5290-6 
Figure legends

Fig. 1: Immunodetection of hCG at the human implantation site.

16 wk-placenta paraffined serial sections were fixed for $4 \mathrm{~h}$ and immunostained for hCG using the A0231 antibody (A) and the HT13 antibody (B). Ki67 immunostaining was performed to detect proliferative cells (C), and isotypic IgG1 was used as control (D). Magnificance : x 400 p: proximal column; i: invasive evct; e: endovascular evct; usa: uterine spiral artery (panel A).

Fig. 2: Immunodetection of hCG in extravillous cytotrophoblast.

A, Scheme of an anchoring villus. sc: stromal core; vct: villous cytotrophoblast; st: syncytiotrophoblast; fv: floating villi; is: intervillous space; av: anchoring villi; evct: extravillous cytotrophoblast; p: proliferative evct; i: invasive evct; e: endovascular evct; gc: giant cells; d: decidual cells; usa: uterine spiral artery. Panels B to F depict hCG immunodetection using the HT13 antibody: B. a section of floating villi; C. a giant cell; D. a section of profound myometrium; E, proximal and distal column of EVCT with invasive EVCT; F, a uterine remodelled artery invaded by endovascular EVCT. Bar: $20 \mu \mathrm{m}$. Panel $\mathbf{G}$ is a large section showing CK7 positive EVCT and the uterine artery of panel F.

Fig. 3: Immunodetection of hCG and Ki67 in extravillous cytotrophoblast in situ and in vitro. Panels A\&B are serial sections of a paraffined first trimester anchoring villi. A. Immunodetection of hCG with HT13 antibody. B. Immunodetection of Ki67. Bar: $20 \mu \mathrm{m}$; sc: stromal core. C. Immunodetection of hCG (A0231 antibody) and Ki67 in EVCT isolated from first trimester chorionic villi and cultured for $2 \mathrm{~h}$ on Matrigel (D. isotype-matched control). E. Immunodetection of hCG (A0231 antibody) and Ki67 in 48h-cultured EVCT (F. isotype-matched control). Bar: 50 $\mu \mathrm{m}$. 
Fig. 4: Detection of hCG in human cultured villous and extravillous cytotrophoblasts.

A. Villous cytotrophoblasts in culture differentiated from a mononuclear cell to a syncytium over 72 h. B. Extravillous cytotrophoblasts in culture on Matrigel displayed an invasive phenotype, emitted pseudopodia and formed a network as shown at $48 \mathrm{~h}$. Cells were immunostained for hCG using the HT13 antibody and IgG1 was used as an isotypic control. Scale bar: $20 \mu \mathrm{m}$. C. Detection of hCG in ST and EVCT culture medium by immunoblotting using A0231 antibody. D. Comparative secretion of hCG by human VCT and EVCT in culture. Supernatants from 24, 48, and $72 \mathrm{~h}$-cultured VCT and EVCT were collected and total hCG was measured as described in Materials and Methods. Protein secretions were expressed as UI/L and normalized to DNA content for comparison between VCT and EVCT. Values represent the mean \pm SEM of three independent cultures isolated from three different placentas. Mann and Whitney test was used to compare EVCT vs VCT $(* * \mathrm{P}<0.01$ and $* * * \mathrm{P}<0.001)$. Kruskal and Wallis test was used to compare VCT hCG secretions at 24,48 and 72 h of culture $(\$ \mathrm{P}<0.0001)$. 